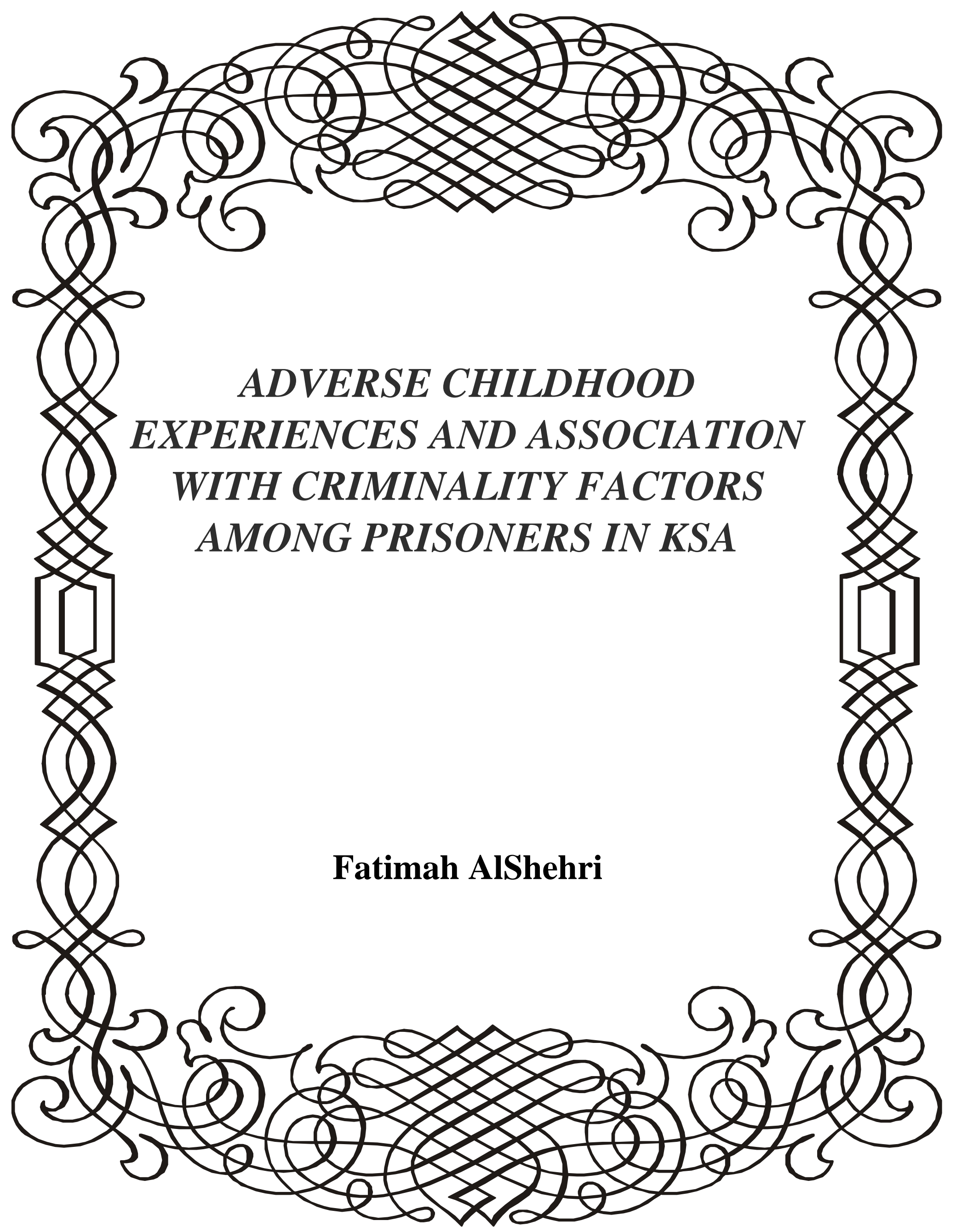


$\longrightarrow$ 


\title{
ADVERSE CHILDHOOD EXPERIENCES AND ASSOCIATION WITH CRIMINALITY FACTORS AMONG PRISONERS IN KSA
}

The author AlShehri, Fatimah. 2017

\begin{abstract}
This study aims to examine the prevalence of various childhood adverse experiences among detainees in KSA and to determine whether the ACE dimensions are associated with criminality factors. Therefore the two main questions of this study are first, what is the prevalence of various childhood adverse experiences among detainees in KSA? Second, are the ACE dimensions associated with criminality factors among detainees in KSA? The present study reports cross sectional data with male detainees at "Malaz" prison in Riyadh. Out of 200 approached prisoners, 156 accepted to enroll in this study. Data was collected from December 2016 to February 2017. The participation in this study was voluntary. The results showed higher percentages of child abuse and neglect among prisoners than in the general community population in KSA (Al Muneef et al., 2016; Al Muneef et al., 2014), The result also showed that the psychological abuse (34\%/few times) was the most prominent type of abuse the prisoners had during childhood followed by physical abuse (23\%/few times). Family relations was the only factor that showed in verse significant relation with number of incarceration. As the number of arrests increases, the family relations and support decrease.
\end{abstract}




\section{هبلة الفدمة الاجتماعية}

ملخص الدر اسة:

هدفت الدراسة إلى التعرف على مدى انتشار تجارب الطفولة السيئة بين السجناء في المملكة العربية السعودية و التعرف على مدى العلاقة بين التعرض لتجارب طفولة سيئة وبين الانحر اف نحو الجريمة لاحقاً لذا تحدد السؤلان الرئيسيان لهذه الدر اسة في أو لا ما مدى انتشار تجار الطفولة السيئة بين السجناء في المملكة العربية السعودية؟ وثانيًا: ما مدى العلاقة بين التعرض لتجارب الطفولة السيئة والانحراف نحو الجريمة لاحقا؟ تم جمع بيانات الدراسة الحالية من سجن الملز بمدينة الرياض في المملكة العربية السعودية في الفترة

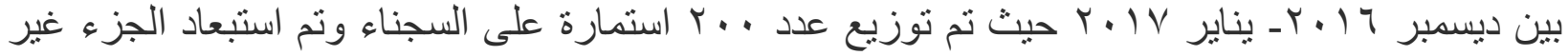
المكتمل لتكون اجمالي العينة 107 استمارة. وقد توصلت الدراسة إلى عدة نتائج من أهمها أن نسبة خبرات الطفولة السيئة كانت أعلى بين عينة السجناء منها لاى عينة طبيعية من المجتمع في دراسة سابقة (المنيف

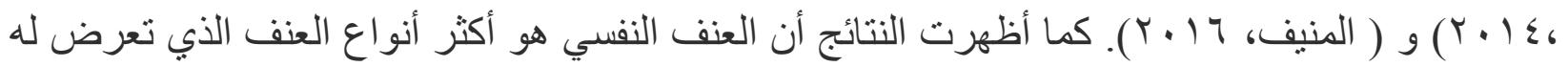
السجناء أثناء طفولتهم بنسبة ؟ب\% ذكروا أنهم تعرضوا له عدة مرات يليه العنف الجسدي بنسبة بr\%\%. الروابط الاسرية كانت العامل الأكثر أهمية من بين مختلف العوامل الأخرى حيث أظهر علاقة ارتباطية عكسية دالة احصائياً بين زيادة عدد مرات دخول السجن و الرو ابط الاسرية بمعنى أنه كلما ضعفت الروابط الأسرية زادت عدد مر ات دخول السجن.

Background 


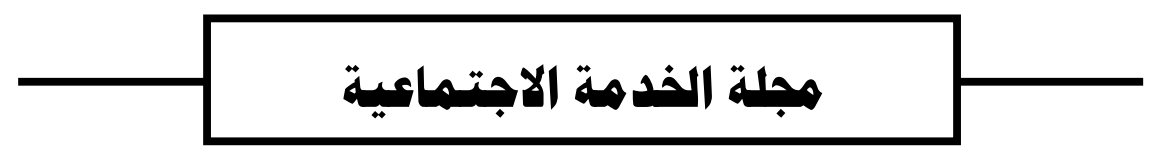

\section{ACE prevalence}

Childhood experiences are a significant public health issue since they have been associated with long term future violence victimization and perpetration, and lifelong diseases and diminished opportunities (CDC 2016). The majority of the initial research in this area has been referred to as Adverse Childhood Experiences (ACEs). Many Adverse Childhood Experiences (ACE) studies measure the childhood traumatic experiences retrospectively and examine its long term negative health outcomes (Hughes et al., 2016). Recent prevalence estimates of ACEs confirm high global prevalence. Data from the original ACE Study showed that almost two-thirds $(63.5 \%)$ of adults had at least one ACE, and $12 \%$ had 4 or more ACEs (Felitti et al., 1991). Another cross sectional population based study that was implemented across 10 states in the United States using data from the Behavioral Risk Factor Surveillance Survey (BRFSS), also found that approximately two-thirds of adults reported at least one early life adversity (Cunningham et al., 2014; fuller Thomson et al., 2013). Other recent longitudinal and cross sectional studies have also reported similar figures (Bellis et al., 2014).

\section{$A C E$ and criminality}

Little research explores the effects of childhood adversity on adults' criminal activity. Available studies among criminal offenders suggest an association between childhood trauma and violent delinquency (Dudeck et al., 2016; Levenson, 2014). A study conducted among 173 male prisoners in the Chalkida prison in Greece (Sergentanis TN, 2014) revealed that $26 \%$ of prisoners disclosed childhood maltreatment that represents a critical factor in the life course of male 
prisoners. Another longitudinal study conducted by Widom and Maxfield (2001) over a period that exceeded 30 years $(\mathrm{N}=1575)$ indicated that a child who experienced child abuse or neglect is $59 \%$ more likely to be arrested during adolescence and $28 \%$ more likely to be arrested during adulthood. Multiple types of childhood adversities have been shown to be associated with subsequent delinquency and problem behaviors in adulthood. For instance, physical abuse during childhood was reported by over $50 \%$ of male offenders in the US and approximately $30 \%$ of offenders reported sexual abuse and sexual offenders were shown to have higher ACE scores than non-offenders in the community (Levenson, 2014). Also in a large study by Fox et al. (2015) among youth offenders suggested that being exposed to combined types of adverse childhood experiences predict violent and chronic juvenile offending. Neglect was also proved to be associated with juvenile delinquency and persistence in crimes (Kerig \& Becker 2015).

\section{Social learning theory}

In the past 30 years, two main theories investigated the aggression in children. Studies based on social learning theory investigate the impact of the social environment on the onset and development of aggression (Bandura, 1973; Feshbach, 1974; Johannesson, 1974). According to Bandura (1973), "People are not born with preformed repertoires of aggressive behavior; they must learn them in one way or another" (p. 61). Bandura's social learning theory explains that children acquire specific behaviors (e.g., aggression) through imitation and reinforcement. A second theory that was based on the social learning paradigm is Patterson's coercion model (Patterson, 1976, 1982). This theory argues that child violent behaviors are a result of family-based reinforcement processes. It differs from the classical social learning theory in the description of the possibility that 
child aggressive behavior may be biologically determined and reinforcement processes may result in maintaining or increasing this behavior (Patterson, 1982). Several studies have confirmed the role of social learning processes in the development of child aggression, and in the treatment and prevention of the expression of antisocial behavior (Bandura, 1973; Johannesson, 1974; Reid, Eddy, Fetrow, \& Stoolmiller, 1999; Snyder, Edwards, McGraw, Kilgore, \& Holton, 1994; Webster-Stratton, Reid, \& Hammond, 2004). Most of these studies based on social learning theory have focused on preschoolers and school-aged children (Bandura, 1973; Snyder et al., 1994)

\section{Current study}

There is paucity of studies linking childhood experiences to adult health in Arab countries (Al Muneef et al., 2016; Shawi et al. 2015) despite the widespread of child maltreatment is this region (Khamis et al., 2000; Al-Ateeqi et al. 2002; Thabet et al. 2004; Al-Mahroos et al. 2005; Al Eissa \& Almuneef et al., 2010). In KSA, Al Muneef et al (2016) conducted a large national study across 13 regions among 10,156 adults and concluded that cumulative ACEs increases the risk of mental problems, risky health behaviors and physical diseases. Also in Iraq, a cross-sectional study that was conducted on 2013-2014, in 13 primary health care centers and eight colleges of three universities in Baghdad showed that an exposure to a high level of household dysfunction and abuse is expected to increase the risk of chronic physical diseases by $81 \%$. Authors also found that higher level of bonding to family is expected to reduce the risk of chronic physical diseases by almost the half. (Shawi et al., 2015). The rest of the studies in Arab countries assess the direct impact of abuse on the emotional and behavioral aspects. Moreover, Usta et al., (2013) reported that abused children had higher trauma symptoms and lower family functioning than non-abused children. 


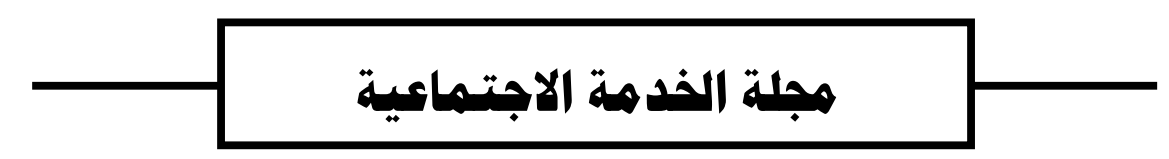

Objectives of the study:

1-This study aims to examine the prevalence of various childhood adverse experiences among detainees in KSA.

2-This study aims to determine whether the ACE dimensions are associated with criminality factors.

Questions of the study:

1- What is the prevalence of various childhood adverse experiences among detainees in KSA?

2- Are the ACE dimensions associated with criminality factors among detainees in KSA?

\section{Methodology}

\section{Participants}

The present study reports cross sectional data with male detainees at "Malaz" prison in Riyadh. Out of 200 approached prisoners, 156 accepted to enroll in this study. Data was collected from December 2016 to February 2017. The participation in this study was voluntary. The study protocol was approved by the ethical committee at the Saudi Social Studies Society and the National Center for Studies and Research and was facilitated by the general administration of the prison.

\section{Data collection}

At the time of sample collection, the objective of the study and the guarantee of confidentiality were explained to the detainees by two social workers who were trained by the main researcher of this study. They all come from a psychology or social work background. After signing an informed consent form, the participants 
completed the questionnaires in a private room, placed them in a sealed envelope and then deposited them in a box.

\section{Measurements:}

Socio demographic questionnaire

This questionnaire was used to collect socio demographic information about current age, marital status, highest educational achievement and occupation.

\section{The ACE questionnaire}

The original ACE questionnaire (Felitti et 1., 1998) was translated to Arabic by Al Muneef et al., (2014) which was adopted for this study after taking the consent of the authors. The questionnaire showed very good psychometric properties with Cronbach alpha varying between 0.813 to 0.940 . The questionnaire included adverse childhood experiences such as verbal, physical, sexual abuse, and neglect. Household dysfunction was also examined in the form of experiencing domestic or interpersonal violence, and the presence of a mentally ill, substance abusing, or incarcerated caregiver prior to the participant's age of 18. ACE-IQ has items related to demographic information (6 items), marriage and family (5 items), family relationship (2 items), neglect (4 items), household dysfunction (9 items), abuse ( 8 items), peer violence (3 items). Abuse and neglect experiences or witnessing domestic violence were evaluated according to their frequency form " $0=$ Never" to " $4=$ too often". For the remaining experiences, the classification is "Yes" or "No".

\section{Delinquency and crime questionnaire}

The criminality variables include: number of arrests, age at first arrest, reason for arrest, age of first incarceration, history of incarceration, length of incarceration.

\section{Analysis}


Microsoft Excel and SPSS were used to calculate the percentages, means and standard deviations of socio demographic, ACEs and criminality factors among these participants.

\section{Results}

Table 1 summarizes the demographic characteristics of the sample. The mean age of the respondents is 33 years, the majority (74\%) are Saudi citizens and 51\% are married. Almost half of the sample finished their secondary level of education and $32 \%$ completed university level. The majority of the respondents are employed with $37 \%$ being workers in private sectors and $24 \%$ in governmental agencies.

The distribution of criminality characteristics of the sample is presented in Table 2. The vast majority $(80.8 \%)$ of the prisoners are incarcerated for the first time at the time of the study and $14.7 \%$ for the second time. As for the cause of arrests, monetary frauds (39\%) were the most prominent crime type and $21.7 \%$ went to prison for property crime including theft, forgery and receipt of stolen good. Others (14\%) were convicted for antisocial behaviors, assaults (8\%) and homicides (7\%). The average length of incarceration is two years and the average age for first imprisonment is 30 years.

The prevalence of different forms of abuse during childhood and the percentage of prisoners who sought psychological treatment are shown in Table $3 \& 4$. Psychological abuse (34\%/few times) was the most prominent type of abuse followed by physical abuse (23\%/few times). $7.7 \%$ admitted being sexually abused in their childhood. Furthermore, almost $20 \%$ of the sample stated that they witnessed one of their household member being treated violently in their childhood. There was significant overlap of abuse within this sample, and the 
likelihood of a participant experiencing more than one type of adversity was to be expected. As for the family support, more than half of the sample $(52 \%)$ reported that they got attention from parents during their childhood. Concerning the reporting of abuse and seeking psychological treatment, only $7 \%$ of victims confessed that they ever reported any abuse act and $8 \%$ received mental health sessions.

Table 5 presents the correlation between child abuse and criminality type. Family relations was the only factor that showed in verse significant relation with number of incarceration. As the number of arrests increases, the family relations and support decrease, and this result support the social leaning theory that person learn in his/her childhood the accepted behavior by watching his/her mom and dad relationship. Children also learn in there early age that the aggressive behavior is normal so they usually use it in there relations. No significant relations were shown with other dimensions of maltreatment. 


\section{همبلة الفدمهة الاجتمعامية}

Discussion

This study focuses on a sample of male prisoners in KSA and aims at studying the magnitude of childhood maltreatment among those special type of population and whether there is a relationship between the different dimensions of negative childhood experiences and criminality factors.

When comparing our findings to previous studies, our results show higher percentages of child abuse and neglect than in the general community population in KSA (Al Muneef et al., 2016; Al Muneef et al., 2014). In our sample, between $11.5 \%$ and $21.2 \%$ of prisoners reported frequent (many times) psychological abuse in their childhood, $21 \%$ experienced frequent physical abuse and $2-11 \%$ affirmed being neglected as children. However, in the national study in KSA the range of percentages of frequent psychological, physical abuse and neglect were as follows $8-17 \% ; 9-12 \%$ and $3-6 \%$ respectively. Our findings also reveal that indicators of household dysfunction were higher for the prisoners than for the community sample. In our study, $13.5 \%$ of the respondents declared that they used to live with a household member who is substance user and $17.3 \%$ lived with incarcerated household member. As for the community sample, the percentages were $9 \%$ and $11 \%$ respectively.

However, the prevalence of sexual abuse in our study (5-7\%) was lower than general community Saudi participants (6-12\%). A possible explanation to this difference is that prisoners maybe reluctant to disclose sexual abuse for fear of abuse, harm or oppression. Also, when discussing the assault, sexual abuse victims may experience discomfort, pain and panic symptoms, and re-experiencing the helplessness of fear of assault (Fruend, K. 1991). As for the other types of maltreatment including peer violence (many times), they record nearly same percentages for both samples were (13\% vs $14 \%)$. 
Our study also highlights the low prevalence of reporting abuse and the seeking of psychological treatment following victimization. A plausible reason is the fear of social stigma in a conservative society and possibly victims don't expect support from their surrounding people; thus, they prefer to remain silent.

Even though the majority of the ACE dimensions were not associated with increases in criminality among the current participants, other studies also found similar results (Jung, Herrenkohl, Klink, Lee, and Brown; 2014). Authors argue that other variables are more likely affecting criminality than the ACE dimensions alone.

\section{Limitations:}

Finally, the limitations of our study need to be noted. This is a cross sectional study and its results rely on recall and willingness to report ACEs even after guaranteeing anonymity. Recollecting childhood issues in adulthood is subjective to recall and other responses bias but evidence suggests that retrospective recall of adverse events in survey data can be valid and reliable (Hardt, Sidor, Bracko, \& Egle, 2006; Hardt, Vellaisamy, \& Schoon, 2010). In addition, as the data is collected from one prison the generalizability of our findings to all male prisoners in KSA may be limited.

\section{Conclusion}

ACEs are experienced by a considerable proportion of male prisoners in KSA. Measuring the magnitude of ACEs among prisoners is important for the prison administration and other social care services organizations to meet the inmate needs. Effective interventions and treatment approaches targeting prisoners to 


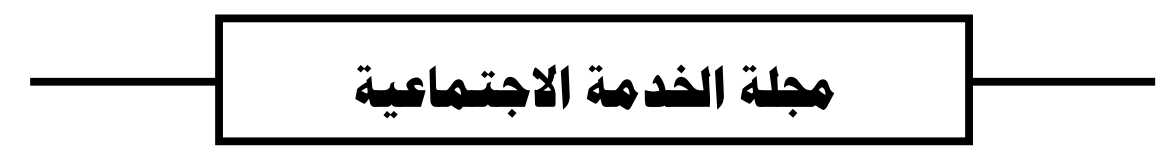

reduce aggressive behaviors would be of great importance. This study will highlighted the important of childhood and its effect on the person future.

References:

1-Almuneef M, Qayad M, Aleissa M, Albuhairan F. Adverse childhood experiences, chronic diseases, and risky health behaviors in Saudi Arabian adults: a pilot study Child Abuse Negl.2014 Nov;38(11):1787-93. doi: 10.1016/j.chiabu.2014.06.003. Epub 2014 Jun 25.

2-Almuneef M, Hollinshead D2, Saleheen H3, AlMadani S3, Derkash B2, AlBuhairan F4, Al-Eissa M5, Fluke J. Adverse childhood experiences and association with health, mental health, and risky behavior in the kingdom of Saudi Arabia. Child Abuse Negl. 2016 Oct;60:10-17. doi: 10.1016/j.chiabu.2016.09.003. Epub 2016 Sep 20.

3-Al-Shawi, A. F., \& Lafta, R. K. (2015). Effect of adverse childhood experiences on physical health in adulthood: Results of a study conducted in Baghdad city. Journal of Family \& Community Medicine, 22(2), 78-84.

4-Al-Ateeqi W, Shabani I, Abdulmalik A. Child abuse in Kuwait: problems in management. Med Princ Pract. 2002 Jul-Sep;11(3):131-5. 


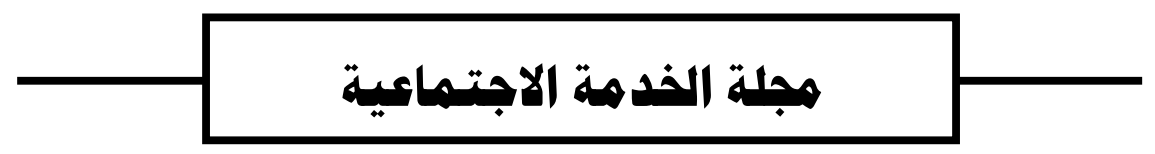

5-Bandura, A. (1973). Aggression: A social learning analysis. Englewood Cliffs, NJ: Prentice-Hall

6-Bellis et al (2014) national household survey of adverse childhood experiences and their relationship with resilience to health harming behaviors in England. BMC Medicine 12:72

7-CDC (2016) Adverse Childhood Experiences (ACEs) Retrieved from https://www.cdc.gov/violenceprevention/acestudy/ [last accessed on 21/2/2017].

8-Cunningham et al (2014) Sex specific relationships between adverse childhood experiences and chronic obstructive pulmonary disease in five states. International journal of COPD 9:1033-1043.

9-Dudeck M, Sosic-Vasic Z, Otte S, Rasche K, et al (2016) The association of adverse childhood experiences and appetitive aggression with suicide attempts and violent crimes in male forensic psychiatry inpatients. Psychiatry Res.30; 240:3527.

10-Felitti V. J., Anda R. F., D. Nordenberg, D. F. Williamson, A. M. Spitz, V. Edwards, M. P. Koss, J. S. Marks Relationship of childhood abuse and household dysfunction to many of the leading causes of death in adults. The Adverse Childhood Experiences (ACE) Study. Am J Prev Med. 1998 May; 14(4): 245-258.

11-Fruend, K. (1991). Caring for the victim of sexual assault (Editorial). American Journal of Preventative Medicine, 7(6): 459 - 460. 
12-Feshbach (1974) the development and regulation of aggression: some research gaps and a proposed cognitive analysis. In J. De Wit \& W.W HArtup (Eds)., determiants and origins of aggressive behavior. Paris: Mouton

13- Fox BH, Perez N, Cass E, Baglivio MT, Epps N. Trauma changes everything: examining the relationship between adverse childhood experiences and serious, violent and chronic juvenile offenders. Child Abuse Negl. 2015 Aug;46:163-73.

14-Fuller-Thomson et al (2013) Gender specific association between childhood adversities and smoking in adulthood: findings from a population- based study. Public Health 127:449-460.

15-Fruend, K. (1991). Caring for the victim of sexual assault (Editorial). American Journal of Preventative Medicine, 7(6): 459 - 460.

16-Hardt J, Sidor A, Bracko M, Egle UT. Reliability of retrospective assessments of childhood experiences in Germany. J Nerv Ment Dis. 2006 Sep;194(9):676-83.

17-Hughes et al (2016) Relationships between adverse childhood experiences and adult mental well-being: results from an English national household survey. BMC public health 16:222

18-Johannesson I (1974) Aggressive behavior among school children related to maternal practives in early childhood In. J. de Wit \& W.W. HArtup (Eds.), determinants and origins of aggressive behavior (pp. 413-425). The Hague Mouton. 
19-Jung H1, Herrenkohl TI2, Klika JB3, Lee JO4, Brown EC5.Does Child Maltreatment Predict Adult Crime? Reexamining the Question in a Prospective Study of Gender Differences, Education, and Marital Status. J Interpers Violence. 2015 Aug;30(13):2238-57. doi: 10.1177/0886260514552446. Epub 2014 Oct 6 .

20-Kerig, P. K., Becker, S. P. (2015). Early abuse and neglect as predictors of antisocial outcomes in adolescence and adulthood. In J. Morizot \& L. Kazemian (Eds.), The development of criminal and antisocial behavior: Theoretical foundations and practical applications (pp. 181-199). New York: Springer. doi: 10.1007/978-3-319-08720-7_12. Published, 01/01/2015.

21-Khamis, V., 2000. Child psychological maltreatment in Palestinian families. Child Abuse Neglect, 24: 1047-1059.

22-Levenson JS., Gwenda M.W, Prescott DS. (2014) Adverse Childhood Experiences in the Lives of Male Sex Offenders Sexual Abuse; 28:4, 340 - 359.

23-Reid, J. B., Eddy, J. M., Fetrow, R. A., \& Stoolmiller, M. (1999). Description and immediate impacts of a preventive intervention for conduct problems. American Journal of Community Psychology,27(4), 483-517. DOI: $10.1023 / \mathrm{A}: 1022181111368$

24-Sergentanis, Theodoros N. et al. Does history of childhood maltreatment make a difference in prison? A hierarchical approach on early family events and personality traits Psychiatry Research, Volume 220, Issue 3, 1064 - 1070 


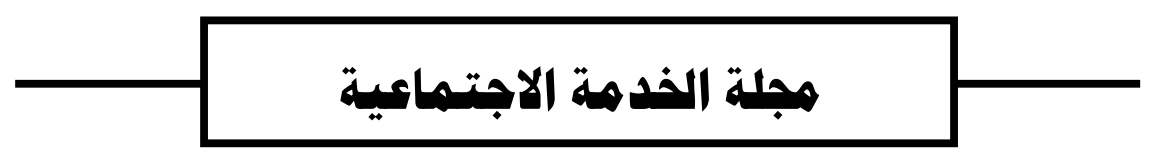

25-Snyder, J., Edwards, P., McGraw, K., Kilgore, K. and Holton, A. (1994) 'Escalation and reinforcement in mother-child conflict: Social processes associated with the development of physical aggression', Development and Psychopathology, 6(2), pp. 305-321. doi: 10.1017/S0954579400004600.

26-Thabet A et al (2004) Maltreatment and coping strategies among male adolescents living in the Gaza strip. Child abuse and Neglect 28:77-91.

27-Widom CS\&Maxfield MG (2001) an update on the "cycle of violence" Wadhington (DC): National institute of Justice 


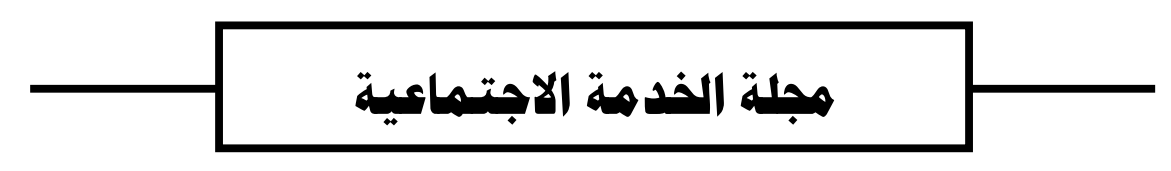

Table 1. Demographic characteristics of the sample $(\mathrm{N}=156)$

\begin{tabular}{|c|c|c|}
\hline Variables & $\mathrm{N}$ & $\%$ \\
\hline \multicolumn{3}{|l|}{ Current age } \\
\hline Mean (SD) & $32.97(10.85)$ & - \\
\hline \multicolumn{3}{|l|}{ Nationality } \\
\hline Saudi & 115 & 73.7 \\
\hline Non Saudi & 39 & 25 \\
\hline \multicolumn{3}{|l|}{ Highest educational level } \\
\hline Illiterate & 1 & 0.6 \\
\hline Didn't complete primary & 2 & 1.3 \\
\hline \multicolumn{3}{|l|}{ education } \\
\hline Primary & 8 & 5.1 \\
\hline Elementary & 12 & 7.7 \\
\hline Secondary & 77 & 49.4 \\
\hline University & 50 & 32.1 \\
\hline Post graduate & 6 & 3.8 \\
\hline \multicolumn{3}{|l|}{ Current employment status } \\
\hline $\begin{array}{l}\text { Employee in governmental } \\
\text { sector }\end{array}$ & 37 & 23.7 \\
\hline Employee in private sector & 57 & 36.5 \\
\hline Business man & 21 & 13.5 \\
\hline Volunteer & 2 & 1.3 \\
\hline Student & 18 & 11.5 \\
\hline Retired & 5 & 3.2 \\
\hline Don't work & 14 & 9 \\
\hline \multicolumn{3}{|l|}{ Current social status } \\
\hline Married & 64 & 41 \\
\hline Divorced or separated & 9 & 5.8 \\
\hline Single & 79 & 50.6 \\
\hline \multicolumn{3}{|l|}{ Age at first marriage } \\
\hline Mean (SD) & $26.45(4.96)$ & - \\
\hline
\end{tabular}

Percentages may not add to 100 due to missing data 


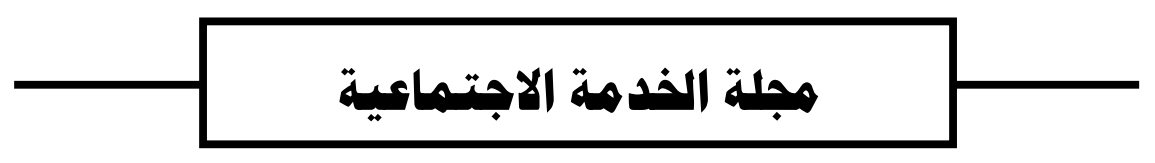

Table 2. Criminality characteristics of the sample $(\mathrm{N}=156)$

\begin{tabular}{|c|c|c|}
\hline Variables & $\mathrm{N}$ & $\%$ \\
\hline \multicolumn{3}{|l|}{ Number of arrests } \\
\hline Many times ( $>=3$ times) & 7 & 4.5 \\
\hline Twice & 23 & 14.7 \\
\hline First time & 126 & 80.8 \\
\hline \multicolumn{3}{|l|}{ Crime type } \\
\hline Monetary frauds & 61 & 39.1 \\
\hline Antisocial behaviors & 22 & 14.1 \\
\hline $\begin{array}{l}\text { Property crime (Robbery, } \\
\text { forgery, receipt of stolen good) }\end{array}$ & 34 & 21.7 \\
\hline $\begin{array}{l}\text { Assaults } \\
\text { (assault/fights/shooting/weapon } \\
\text { threat) }\end{array}$ & 13 & 8.3 \\
\hline Murder & 11 & 7.1 \\
\hline $\begin{array}{l}\text { Traffic violations } \\
\text { (accident/car racing) }\end{array}$ & 4 & 2.5 \\
\hline Cyber bullying/threatening & 2 & 1.2 \\
\hline Drug use & 2 & 1.2 \\
\hline Others & 7 & 4.4 \\
\hline \multicolumn{3}{|l|}{ Period of criminality } \\
\hline Mean (SD) & $2.41(3.87)$ & - \\
\hline \multicolumn{3}{|l|}{ Age of first incarceration } \\
\hline Mean (SD) & $\begin{array}{l}30.34 \\
(10.46)\end{array}$ & - \\
\hline
\end{tabular}

Responses may not add to 100 due to missing data 


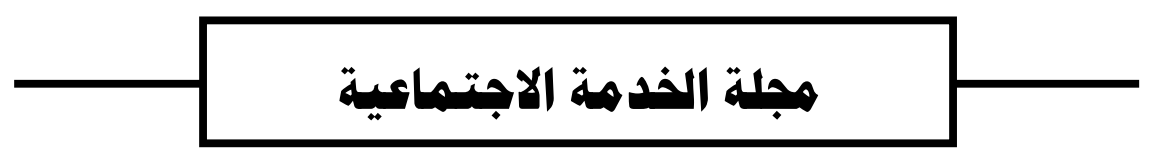

Table 3: Prevalence of different forms of family dysfunction during childhood $(\mathrm{N}=156)$

\begin{tabular}{lll}
\hline Family dysfunction & Yes & No \\
& $\mathrm{N}(\%)$ & $\mathrm{N}(\%)$
\end{tabular}

\begin{tabular}{lll}
\hline Household member was an alcohol user or drug $21(13.5)$ & $135(86.5)$
\end{tabular}

user

Household member had depression/mental

illness/suicidal

$10(6.4) \quad 146(93.6)$

Household member was incarcerated

$27(17.3)$

$129(82.7)$

Parents divorced/separated

$18(11.5)$

$138(88.5)$

Parents died

$28(17.9)$

$128(82.1)$

Percentages may not add to 100 due to missing data 
Table 4: Prevalence of different forms of abuse during childhood and reporting and seeking psychological help $(\mathrm{N}=156)$

Forms of abuse

Many times

$\mathrm{N}(\%)$
Few times Never

$\mathrm{N}(\%) \quad \mathrm{N}(\%)$

\section{Family relations}

$\begin{array}{llllll}\text { Getting enough attention from } 81(51.9) & 61(39.1) & 14(9)\end{array}$ parents

Parents are aware of child's free time $70(44.9) \quad 63(40.4)$ activities

\section{Domestic violence}

Household member treated violently

Scream, swear, insult or humiliate 21 (13.5) 31 (19.9)

$104(66.7)$

you

Spank, slap, kick, punch or beat you

$15(9.6)$

$30(19.2)$

$111(71.2)$

Hit you with an object

17 (10.9)

31 (19.9)

108 (69.2)

Mother being treated violently

3 (1.9)

$20(12.8)$

$133(85.3)$

\section{Child abuse}

Psychological abuse

Scream, swear, insult or humiliate 33 (21.2) 53 (34.0)

70 (44.9)

you

Threaten to abandon or throw you $18(11.5) \quad 26(16.7)$

$112(71.8)$

Physical abuse

Spank, slap, kick, punch or beat you

$36(23.1)$

$87(55.8)$

Hit you with an object

32 (20.5)

35 (22.4)

$89(57.1)$

Sexual abuse

Touch or fondle you in a sexual way 3 (1.9)

$12(7.7)$

$141(90.4)$ 


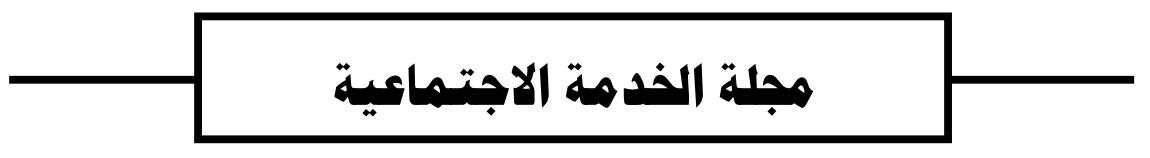

Make you touch their body in a $4(2.6) \quad 11(7.1) \quad 141(90.4)$ sexual way

$\begin{array}{llll}\text { Attempt intercourse with you } & 1(0.6) & 7(4.5) & 148(94.9)\end{array}$

$\begin{array}{llll}\text { Actually have intercourse } & 1(0.6) & 8(5.1) & 147(94.2)\end{array}$

Neglect

Parents not giving enough food $\quad 17(10.9) \quad 23(14.7) \quad 116(74.4)$

Parent/Guardian too drunk to take $3(1.9) \quad 5(3.2) \quad 148(94.9)$

care

Neglect for sending school $\quad 7(4.5) \quad 10(6.4) \quad 139(89.1)$

Neglect in medical treatment $\quad 9(5.8) \quad 19(12.2) \quad 128(82.1)$

Peer violence/bullying

Peer violence/bullying

$22(14.1) \quad 40(25.6) \quad 94(60.3)$

Involved in physical fight $\quad 33(21.2) \quad 55(35.3) \quad 68(43.6)$

Report of abuse

Reporting abuse

$5(3.2)$

$11(7.1)$

$140(89.7)$

Psychological help

$4(2.6)$

$13(8.3)$

$139(89.1)$

Percentages may not add to 100 due to missing data 


\section{هبلة الخدمة الاجتهاعية}

Table 5. Correlations between ACE types and criminality

\begin{tabular}{|c|c|c|c|c|c|c|c|c|c|c|}
\hline & Family re & ations & Neglect & & $\begin{array}{l}\text { Family } \\
\text { dysfuncti }\end{array}$ & & Abuse & & Bullying & \\
\hline & $\begin{array}{l}\text { Pearson } \\
\mathrm{r}\end{array}$ & $\mathrm{P}$ value & $\begin{array}{l}\text { Pearson } \\
\mathrm{r}\end{array}$ & $\mathrm{P}$ value & $\begin{array}{l}\text { Pearson } \\
\mathrm{r}\end{array}$ & $\begin{array}{l}\mathrm{P} \\
\text { value }\end{array}$ & $\begin{array}{l}\text { Pearson } \\
\mathrm{r}\end{array}$ & P value & $\begin{array}{l}\text { Pearson } \\
\mathrm{r}\end{array}$ & $\mathrm{P}$ value \\
\hline $\begin{array}{l}\text { Number of } \\
\text { incarceration }\end{array}$ & -0.199 & $0.016^{*}$ & 0.221 & 0.036 & -0.012 & 0.908 & -0.041 & 0.701 & -0.100 & 0.349 \\
\hline $\begin{array}{l}\text { Types of } \\
\text { criminal } \\
\text { behavior }\end{array}$ & 0.169 & 0.112 & 0.011 & 0.921 & 0.183 & 0.085 & 0.108 & 0.309 & -0.030 & 0.779 \\
\hline
\end{tabular}


هبلة الفدهة الاجتماعية 